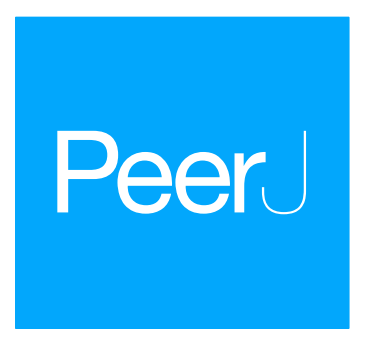

Submitted 9 October 2017 Accepted 27 February 2018 Published 6 June 2018

Corresponding authors Angélica Arenas-Rodríguez, angelica.arenas@javeriana.edu.co Julio Mario Hoyos,

jmhoyos@javeriana.edu.co

Academic editor Philip Reno

Additional Information and Declarations can be found on page 18

DOI 10.7717/peerj.4525

Copyright

2018 Arenas-Rodríguez et al.

Distributed under

Creative Commons CC-BY 4.0

OPEN ACCESS

\section{Comparative description and ossification patterns of Dendropsophus labialis (Peters, 1863) and Scinax ruber (Laurenti, 1758) (Anura: Hylidae)}

\author{
Angélica Arenas-Rodríguez ${ }^{1, *}$, Juan Francisco Rubiano Vargas ${ }^{2}$ and \\ Julio Mario Hoyos ${ }^{1, *}$ \\ ${ }^{1}$ Facultad de Ciencias, UNESIS (Unidad de Ecología y Sistemática), Pontifica Universidad Javeriana, Bogotá, \\ Colombia \\ ${ }^{2}$ Facultad de Ciencias, Universidad del Bosque, Bogotá, Colombia \\ These authors contributed equally to this work.
}

\section{ABSTRACT}

Although comparative studies of anuran ontogeny have provided new data on heterochrony in the life cycles of frogs, most of them have not included ossification sequences. Using differential staining techniques, we observe and describe differences and similarities of cranial and postcranial development in two hylid species, Scinax ruber (Scinaxinae) and Dendropsophus labialis (Hylinae), providing new data of ontogenetic studies in these Colombian species. We examined tadpoles raining from Gosner Stages 25 to 45 . We found differences between species in the infrarostral and suprarostral cartilages, optic foramen, planum ethmoidale, and gill apparatus. In both species, the first elements to ossify were the atlas and transverse processes of the vertebral column and the parasphenoid. Both species exhibited suprascapular processes as described in other hylids. Although the hylids comprise a large group (over 700 species), postcranial ossification sequence is only known for 15 species. Therefore, the descriptions of the skeletal development and ossification sequences provided herein will be useful for future analyses of heterochrony in the group.

Subjects Biodiversity, Developmental Biology, Evolutionary Studies, Taxonomy, Zoology Keywords Ossification sequences, Tadpoles, Skeletal development

\section{INTRODUCTION}

Comparative morphological descriptions for a specific group of frogs have provided useful systematic characters since 1960 (e.g., Cannatella, 1999; Duellman, Marion \& Hedges, 2016). However, most studies of frog morphological characters focus on adults (Faivovich, 2002; Faivovich et al., 2005; Maglia, Pugener \& Mueller, 2007; Wiens et al., 2010; Pyron \& Wiens, 2011; Yildirim \& Kaya, 2014; Duellman, Marion \& Hedges, 2016), and tadpoles have often been overlooked (Alcalde et al., 2011). Of those comparative studies that examine tadpoles, most consider external morphological characters and skeletal characters are often neglected (Fabrezi \& Lavilla, 1992; Faivovich, 2002; Maglia, Pugener \& Mueller, 2007; Hoyos et al., 2012; Yildirim \& Kaya, 2014). When skeletal features are considered, the chondrocranium is most often described, while the postcranium is frequently ignored 
(e.g., Orton, 1953; Starrett, 1973; Wassersug, 1980; Wassersug \& Heyer, 1988; Haas, 2003). However, as with other groups, relatively few detailed comparative morphological studies of hylid tadpole skeletal development have been completed. Given the diversity and recent taxonomic rearrangements of the hylids (Duellman, Marion \& Hedges, 2016; Jungfer, 2017) is important to amass as much comparative information about the group as possible. Thus, there continues to be a pressing need to conduct comprehensive comparative studies of hylids developmental morphology.

Interspecific variations in morphology help to clarify taxonomic groups within in the Hylidae. The family is predominantly distributed across the Neotropical region (Frost, 2018; Duellman, Marion \& Hedges, 2016) and comprises 706 species grouped into seven subfamilies: Acridinae, Cophomantinae, Dendropsophinae, Hylinae, Lophyophylinae, Pseudinae, and Scinaxinae (Faivovich et al., 2005; Wiens et al., 2010; Duellman, Marion \& Hedges, 2016; Frost, 2018). Ossification sequences are known for only 15 species, and only eight of those include the postcranial skeleton: Acris blanchardi (Havens, 2010; Maglia, Pugener \& Mueller, 2007), Boana lanciformis (former Hyla lanciformis, De Sá, 1988), Boana pulchella (former Hypsiboas pulchellus Hoyos et al., 2012), Dryophytes chrysoscelis (former Hyla chrysoscelis, Shearman \& Maglia, 2014), Dryophytes versicolor (former Hyla chrysoscelis, Sheil et al., 2014), Hyla orientalis (Yildirim \& Kaya, 2014), Osteopilus septentrionalis (Sheil et al., 2014), Pseudacris crucifer (Havens, 2010).

Because identifying variations in developmental morphology and ossification sequence can lead to informative phylogenetic characters (Weisbecker \& Mitgutsch, 2010; Harrington, Harrison \& Sheil, 2013), we provide a detailed anatomical comparison of the cranial and postcranial development (including the sequence of onset of ossification) between two species of Andean hylids, Dendropsophus labialis and Scinax ruber.

\section{MATERIALS AND METHODS}

We cleared and double stained for bone and cartilage. We made some changes to the standard protocol of Dingerkus \& Uhler (1977): (1) proportion of ethanol (SIGMA Ref. 459836-2L) and acetic acid (SIGMA Ref. K36101663 620) was changed to 70:30; (2) the Alcian blue (SIGMA Ref. A5268-25G) was increased to $75 \mathrm{mg} /$ add volume, which was dissolved in ethanol and acetic acid; and (3) staining duration of this last solution was increased to $72 \mathrm{~h}$. A number of specimens in our series of $S$. ruber did not show clear staining, thus we increased our sample size. The sample size for tadpoles and metamorphs of $D$. labialis was $N=32$, and $S$. ruber was $N=114$. The number in each series corresponds to the availability of specimens stored at the Museo de Historia Natural "Lorenzo Uribe" at the Universidad Javeriana (MUJ) and the Instituto de Ciencias Naturales at the Universidad Nacional in Bogotá-Colombia (ICN). The larval stages of D. labialis were collected from the Municipio Tenjo, Cundinamarca Departament, 3,200 m (MUJ 9250). The larval stages of S. ruber were collected from the Mun. Neiva, Huila Dep., 570 m; Mun. Granada, Meta Dep., 470 m (MUJ 3727, MUJ 6178, ICN 46015-46017). Tadpoles and metamorphs were staged according to Gosner's (1960).

Observations and photographs were made with a stereomicroscope (Advanced Optical: Amersham, UK (stereoscopes), and Ottawa, Canada (cameras)) connected to a camera 


\begin{tabular}{|c|c|c|c|}
\hline \multirow[t]{2}{*}{ Rank } & \multirow{2}{*}{$\begin{array}{l}\text { Gosner stage } \\
\text { (Number of } \\
\text { specimens) }\end{array}$} & \multicolumn{2}{|c|}{ Elements ossified } \\
\hline & & Cranium & Postcranium \\
\hline \multirow{2}{*}{ I } & $\begin{array}{l}26(3), 27(3), 28(2), \\
29(2), 31(3), 32(1), \\
33(1), 34(1)\end{array}$ & & \\
\hline & $35(1)$ & & Transverse process I-V \\
\hline II & $36(2)$ & Parasphenoid & Transverse process VI-VIII \\
\hline III & $37(3)$ & Frontoparietal, exoccipital & Neural arches I-VIII \\
\hline IV & $38(1)$ & & Hypochord \\
\hline V & $41(3)$ & & $\begin{array}{l}\text { Femur, tibiofibula, humerus, ilium, } \\
\text { radioulna, clavicle, pubis, metatarsal } \\
\text { III-V, coracoids }\end{array}$ \\
\hline VI & $42(3)$ & & Metacarpal IV, urostyle \\
\hline VII & $45(1)$ & $\begin{array}{l}\text { Mentomeckelian, } \\
\text { premaxilla, maxilla, } \\
\text { angulosplenial, dentary }\end{array}$ & $\begin{array}{l}\text { Manus IV proximal phalange, } \\
\text { Metacarpal III and V, scapula, pedal } \\
\text { digit IV proximal phalange, Metacarpal I } \\
\text { and II, metatarsal I, prepollex }\end{array}$ \\
\hline VIII & $46(1)$ & $\begin{array}{l}\text { Neopalatine, nasal, } \\
\text { pterygoid, vomer, } \\
\text { septomaxilla, squamosal }\end{array}$ & \\
\hline
\end{tabular}

(Infinity 1; Lumenera Corporation, Ottawa, Canada) with white LED light and Image Pro Insight program (version 8.0.3). The drawings were made using a digitizing tablet (Bamboo Connect pen; Wacom, Portland, OR, USA) and edited using Adobe Illustrator 5. Anatomical nomenclature for tadpoles follows Parker (1876), Higgins (1921), Jolie (1962), Roček (1981), Duellman \& Trueb (1986), Haas (1995); Haas (1997), Hall \& Larsen (1998), Maglia \& Pugener (1998), Cannatella (1999), Haas (1999), Sheil \& Alamillo (2005), Pugener \& Maglia (2007), Bowatte \& Meegaskumbura (2011), Hoyos et al. (2012), adult nomenclature is based on Avilán \& Hoyos (2006), using the Latin names given by the ICVAN (1973).

The ossification sequence was determined by the first appearance of ossified bone. We refer to the metamorphic climax (MC) sensu Banbury \& Maglia (2006) as the Gosner stages (GS) at which major modifications and fundamental structural changes occur, resulting in the loss of most of the larval characters. We also used the term "rank" to refer to the ordinal number within an ossification sequence at which an element begins to ossify. We note the first time any specimen at that stage showed stain. If two or more elements begin ossifying at the same time (Gosner stages), they were assigned the same rank (i.e., a tie) as per Nunn \& Smith (1998).

\section{RESULTS}

Skeletal development and sequence of onset of ossification of the cranial and postcranial elements of D. labialis and S. ruber are showed in Tables 1 and 2. Many young specimens 


\begin{tabular}{|c|c|c|c|}
\hline \multirow[t]{2}{*}{ Rank } & \multirow{2}{*}{$\begin{array}{l}\text { Gosner stage } \\
\text { (Number of } \\
\text { specimens) }\end{array}$} & \multicolumn{2}{|c|}{ Elements ossified } \\
\hline & & Cranium & Postcranium \\
\hline \multirow{2}{*}{ I } & $\begin{array}{l}26(3), 29(8), \\
30(7), 31(9), 32(8), \\
33(9), 34(9), 35(14)\end{array}$ & & \\
\hline & $36(10)$ & Parasphenoid & Transverse process I-VII \\
\hline II & $37(11)$ & & Neural arch I-III \\
\hline III & $38(4)$ & Frontoparietal, exoccipital & $\begin{array}{l}\text { Transverse process VIII, neural arch } \\
\text { IV-VIII }\end{array}$ \\
\hline \multirow{2}{*}{ IV } & $39-40(3)$ & & $\begin{array}{l}\text { Femur, tibiofibula, humerus, ilium, } \\
\text { radioulna, scapula, hypochord }\end{array}$ \\
\hline & $41(4), 42(5)$ & & \\
\hline \multirow{2}{*}{$\mathrm{V}$} & $43(3)$ & & Ischium \\
\hline & $44(4), 45(2)$ & & \\
\hline VI & $46(1)$ & $\begin{array}{l}\text { Mentomeckelian, premax- } \\
\text { illa, maxilla, angulosplenial, } \\
\text { dentary, neopalatine, ptery- } \\
\text { goid, vomer, septomaxilla, } \\
\text { squamosal }\end{array}$ & \\
\hline
\end{tabular}

(between stages 26 and 35) stained poorly. However, we had sufficient sample size assess ossification sequence. Specimens older than stage 35 stained more reliably.

\section{Chondrocranium}

We observed similar changes in the shape, size, and modification of structures in the development of chondrocranium in the two species. The elements of the skeleton were compared according to the initiation of ossification and not with a specific stage, because in the two study species the ossification occurred in different Gosner stages (Table 3). The overall width of the chondrocranium in D. labialis and S. ruber is roughly $80-90 \%$ of the total length (Fig. 1). The chondrocranium in D. labialis is wider (dorsal view) and lower (lateral view) than S. ruber (Figs. 1A-1C). Basicranial fenestrae did not differentiate with Alcian Blue in either species. We perceived a stronger blue coloration in D. labialis, and the jugular, prootic, and oculomotor foramen were clearly defined, whereas in S. ruber we could not see the oculomotor foramen.

The cartilaginous regions of the taenia tecti medialis and tectum sinoticum both represent a quarter of the basis cranii, extending from the frontoparietal fontanelle in both species. The tectum nasi roofs the nasal region, and the ethmoid plate forms the floor. The tectum nasi is separated from the orbit by a wall, the lamina orbitonasalis (=planum antorbitale sensu Cannatella, 1999). Because these regions are weakly chondrified, the lamina orbitonasalis is not observable in the tadpole stages, and the nasal capsules become visible after metamorphic climax (stage 42 and beyond). The taenia tecti marginalis is evident and clearly differentiated by GS37 in D. labialis and by GS35 in S. ruber. In neither 


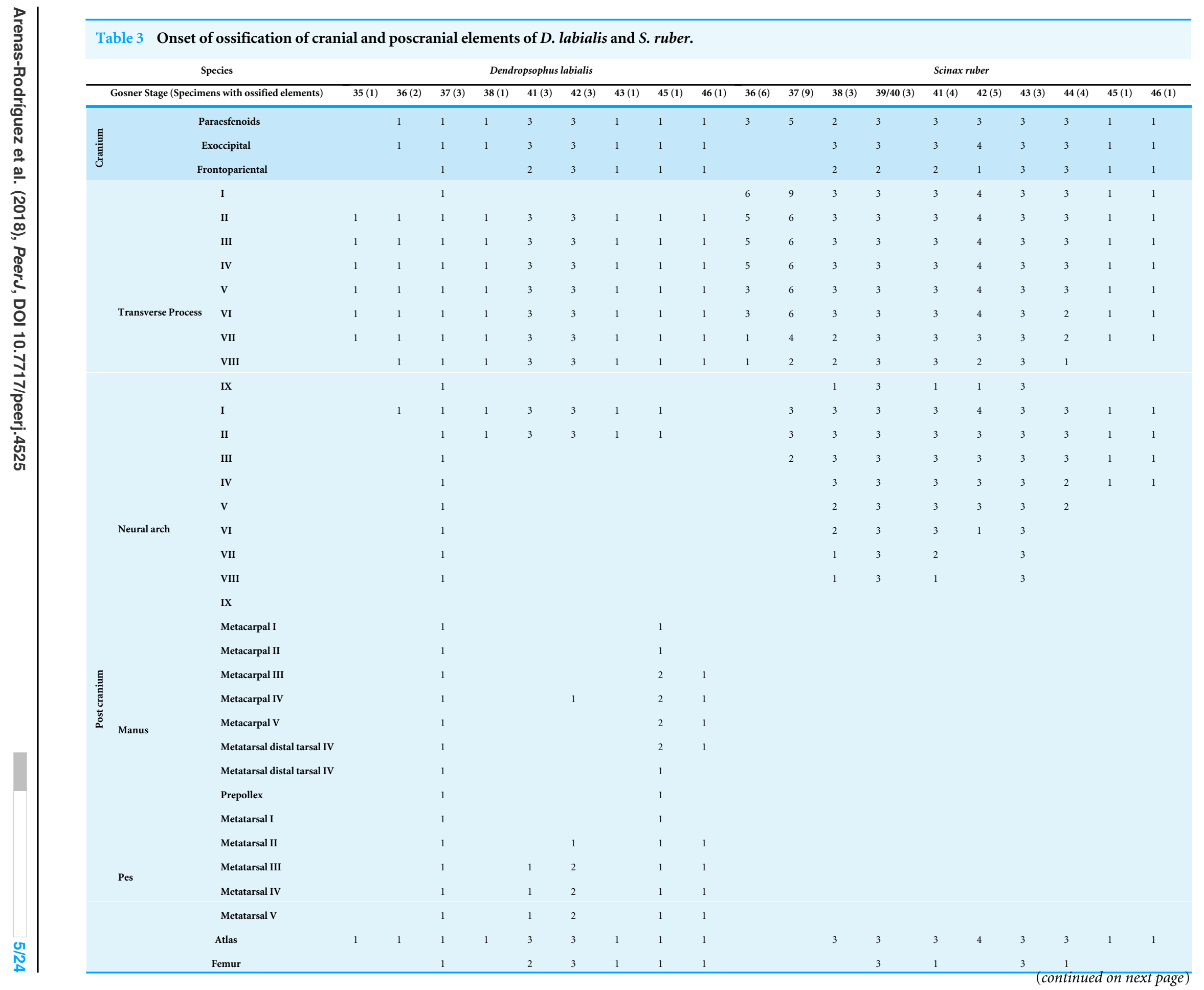




\begin{tabular}{|c|c|c|c|c|c|c|c|c|c|c|c|c|c|c|c|c|c|c|c|}
\hline & & & & & & & & & & & & & & & & & & & \\
\hline Gosner Stage (Specimens with ossified elements) & $35(1)$ & $36(2)$ & $37(3)$ & $38(1)$ & $41(3)$ & $42(3)$ & $43(1)$ & $45(1)$ & $46(1)$ & $36(6)$ & $37(9)$ & $38(3)$ & $39 / 40(3)$ & $41(4)$ & $42(5)$ & $43(3)$ & $44(4)$ & $45(1)$ & $46(1)$ \\
\hline Fibula & & & 1 & & 2 & 3 & 1 & 1 & 1 & & & & & & & & & & \\
\hline Tibia & & & 1 & & 2 & 3 & 1 & 1 & 1 & & & & & & & & & & \\
\hline Tibiofibula & & & 1 & & 2 & 3 & 1 & 1 & 1 & & & & 3 & 1 & 1 & 3 & 1 & 1 & \\
\hline Scapula & & & 1 & & 2 & 2 & & 1 & 1 & & & & 3 & 1 & & 3 & & & \\
\hline Suprascapula & & & 1 & & 2 & 2 & & 1 & 1 & & & & & & & & & & \\
\hline Clavicle & & & 1 & & 2 & 2 & & 1 & 1 & & & & 3 & 1 & & 3 & & 1 & \\
\hline Coracoids & & & 1 & & 2 & 2 & & 1 & 1 & & & & & & & & & & \\
\hline Humerus & & & 1 & & 2 & 3 & 1 & 1 & 1 & & & & 1 & 1 & & 3 & & & \\
\hline Ulna & & & 1 & & & & & & & & & & & & & & & & \\
\hline Radioulna & & & 1 & & 2 & 3 & 1 & 1 & 1 & & & & 3 & 3 & & 3 & & & \\
\hline
\end{tabular}


Dendropsophus labialis

A

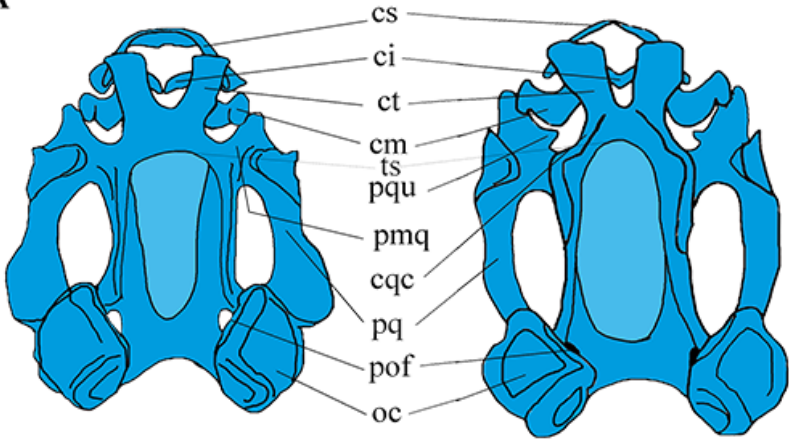

B
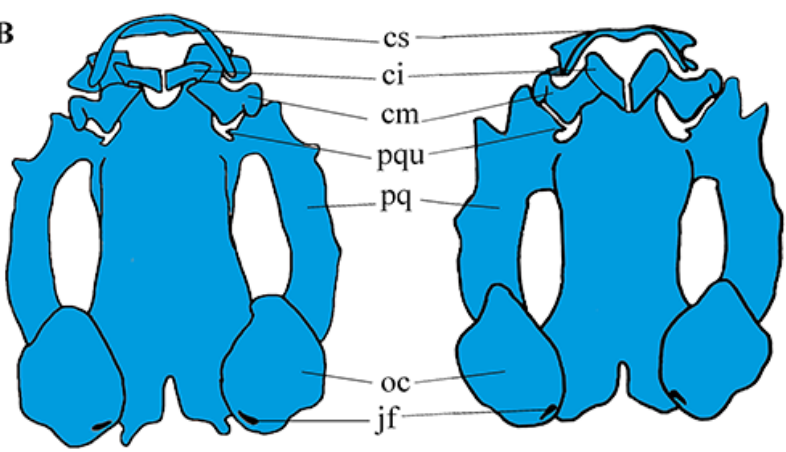

C

D. labialis

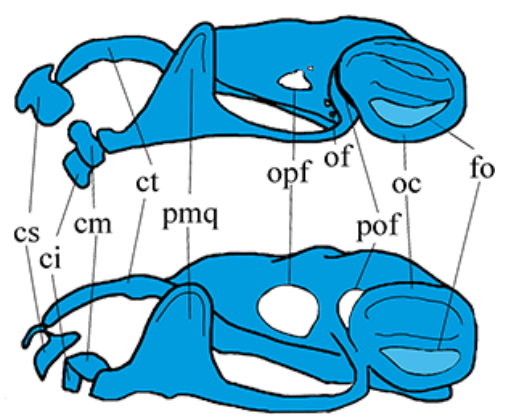

S. ruber

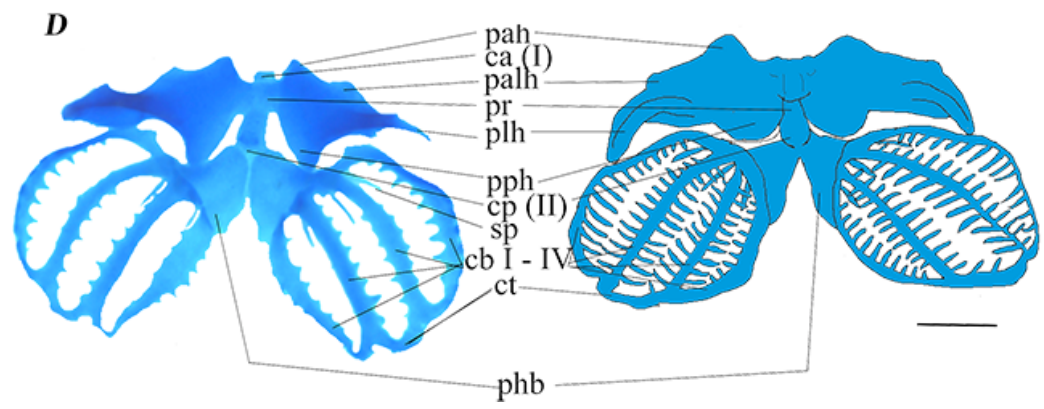

Figure 1 Larval chondrocranium of D. labialis (GS 34 - MUJ 9250) and S. ruber (GS 34 - MUJ 6178). (A) Dorsal view, (B) Ventral view, (C) Lateral view, (D) Ventral view of hyobranchial apparatus in D. labialis (GS36 - MUJ 9250) and S. ruber (GS36 - MUJ 3727). Scale $1 \mathrm{~mm}$. Chondrocranium: a, alae suprarostralis; ci, cartilago infrarostralis; $\mathrm{cm}$, cartilago Meckeli; cqc, commissura quadratocranialis; cs, suprarostral cartilage; ct, cornu trabeculae; fo, fenestra ovalis; jf, jugular foramen; pal, processus anterolateralis; pmq, processus muscularis quadrati; pof, prootic foramen; pq, palatoquadrate; oc, otic capsule; of, oculomotor foramen; opf, optic foramen, ts, tectum sinoticum. Hyobranchial apparatus: ca (I), copula anterioris; cb I-IV; ceratobranchialis I-IV; cp (II), copula posterioris; ct; commissura terminalis; pah, processus anterioris hyalis; palh, processus anteriolateralis hyalis; phb, planum hypobranchiale; plh, processus lateralis hyalis; pph, processus posterioris hyalis; pr, pars reuniens; pqu, processus quadrato ethmoidale; sp, spicula. Blue: cartilage, light blue: fontanella.

Full-size DOI: 10.7717 /peerj.4525/fig-1

species did we observe a frontoparietal fenestra, nor was a taenia tecti transversalis visible on the edge of the frontoparietal fontanelle (Fig. 1A).

Suprarostral cartilage. In both species, the suprarostral cartilage is composed of a discontinuous cartilaginous plate divided into a corpus suprarostralis and a pars alaris; 
posterolaterally we observed a distal syndesmotic junction between the corpus and the ala. The ala has three processes: two rounded anterolateral processes that join syndesmotically with the cornu trabeculae, and one process posterolaterally (Fig. 1C). Fenestrations were not observed in the suprarostral cartilage, nor in the adrostral cartilage near the processus posterodorsalis (=processus dorsalis posterior, sensu Bowatte \& Meegaskumbura, 2011). In D. labialis the corpus suprarostral is curved, while in S. ruber it is straighter and wider distally, articulating proximally with the cornu trabecula (trabecular horn, sensu Cannatella, 1999). The cornua trabecula are approximately $35 \%$ of the total length of chondrocranium (lateral view) in both species, but they are shorter and narrower in D. labialis than in S. ruber. The cornu trabeculae articulate anteriorly with the corpus rostrale and laterally with the pars alaris of the suprarostral cartilage.

Cartilago Meckeli. The cartilago Meckeli (=Meckel's cartilage, sensu Cannatella, 1999) has three processes: the retroarticular (short and blunt), the dorsomedial, and the ventromedial. These processes articulate with the infrarostral cartilage (commissura intramandibularis, sensu Cannatella, 1999) which is composed of two syndesmotically, joined flat plates, and the processus muscularis quadrati. The shape of the processus dorsomedialis and the processus ventromedialis are the same in both species. The palatoquadrate cartilage and the commissura quadratocranialis are joined anteriorly to the base cranii. Laterally, the palatoquadrate cartilage forms the arcus subocularis. The process muscularis quadrati is joined to the processus antorbitalis (=pars plana sensu Parker, 1876; = lamina externa sensu Higgins, 1921; = processus antorbitalis sensu (Roček, 1981); = triangular plane sensu Hall \& Larsen, 1998 = cartilaginous planum triangulare sensu Pugener \& Maglia, 2007) anterolaterally, projecting above the cornu trabecula. The processus hyoquadrati of the palatoquadrate cartilage articulates ventrally with the ceratohyalia of the hyobranchial apparatus (Fig. 1D).

Otic capsule. This structure is longer and higher than wide, occupying about a fifth of the total length of the skull. The crista parotica exhibits a more pronounced lateral projection in D. labialis than in S. ruber. The crista parotica is laterally developed, forming a small processus posterolateralis (=processus lateralis posterior sensu Bowatte \& Meegaskumbura, 2011) and a small processus anterolateralis (more developed in D. labialis). The processus anterolateralis projects vertically, descending obliquely and overlapping the ventral posterolateral margin of the palatoquadrate cartilage. The otic capsule is perforated by the fenestra ovalis, which occupies about $20 \%$ of the otic capsule.

Hyobranchial apparatus. The large ceratohyal has a processus anterioris hyalis, a processus posterioris hyalis, and a processus anterolateralis hyalis. The first two processes are longer than the third, which extends to meet the transverse crease of the processus lateralis hyalis.

The basihyal plate is oval and extends proximally to the copula anterior (=Basibranchial I sensu Duellman \& Trueb, 1986; = basihyale sensu Haas, 1995; Haas, 1997; = copula I sensu Maglia \& Pugener, 1998; Sheil \& Alamillo, 2005) in D. labialis, but is absent in S. ruber. The basibranchial plate is semi-oval and located between the two hypobranchial plates (=planum hypobranchiale sensu Haas, 1999; = plate hyoid sensu Maglia \& Pugener, 1998; = hyobranchial plate sensu Sheil \& Alamillo, 2005), and a branchial bridge is present 
in both species, being wider in S. ruber than in D. labialis. The junction between each ceratobranchium and the planum hypobranchiale is syndesmotic. The ceratobranchia are united posteriorly by the commissura terminalis and bear three spicules anteriorly (Fig. 1D).

The chondrocranial morphology and hyobranchial apparatus is generally similar between the species examined here and those previously studied. However, we did identify several differences between S. ruber and D. labialis, including: (1) the shape of the suprarostral, (2) the size and width of infrarostral cartilages, (3) the length of processus articularis, (4) the thickness of palatoquadrate, (5) the size of optic foramen, (6) the presence of an operculum and processus posterolateralis of the otic capsule, (7) the thickness of the processus muscularis quadrati, (8) the attachment of the ascending process to the braincase, (9) the thickness of the planum ethmoidale, (10) the development of the branchial apparatus, (11) the presence of the copula I, and (12) the type of junction between the ceratobranchia and planum hypobranchiale (Figs. 1 and 2). These differences likely represent species specific differences between the two taxa examined.

\section{Appendicular skeleton}

Shoulder girdle. The pectoral girdle is arciferal in both species. The earliest ossification of the clavicle, coracoid, and scapula appears at GS36 (Fig. 3A). The clavicle and the cleithrum are distinct, and an epicoracoid cartilage is prominent between the clavicle and the coracoid. The epicoracoids are not mineralized. In D. labialis the omosternum is elongated, and the sternum has two projections. The omosternum and the sternum are oval in S. ruber. The clavicle articulates with the coracoid, which is ossified in D. labialis at GS41 and in S. ruber at GS46. The sternum is formed by the epicoracoid and the mesosternum, which joins the medial junction of the epicoracoids (Fig. 2B).

Pelvic girdle. In both species, the primordium of the ilium appears at GS34 and is fully developed by GS41. The ilium begins to ossify by GS41 in D. labialis and by GS39/40 in S. ruber and articulates anteriorly with the ventral surface of the lateral margin of the sacral diapophyses by GS42. The iliac crest appears dorsally prominent. The primordia of the pubis and the ischium appear at GS36, and are synchondrotically fused by GS38 in both species. The sacral diapophyses is wider in D. labialis that in S. ruber. The pubis is completely fused by GS40. The pelvic girdle is completely ossified with the halves fused at the midline, extending anterodorsally forming an angle of $55^{\circ}$ with the head of the femur by GS45 (Fig. 3).

Fore limb and hind limb. The first cartilaginous elements of the forelimbs (radius, ulna, and humerus) appear at GS32, and those of the hindlimbs at GS33 (femur, tibia, and fibula). The tibia and fibula are fused in D. labialis by GS41 and in S. ruber by GS38. We observed ossification of the radius and ulna in D. labialis (GS41) and S. ruber (post metamorphic). The radius and ulna are fused in both species. Primordia of the four carpal and five tarsal elements appear by GS33 and complete development by GS41.

The phalangeal carpal formula is 3-3-4-4 and the phalangeal tarsal formula is 3-3-4-5-4 in both species. Metacarpals are curved and phalanges are cylindrical, having a conical shape at the tip of the terminal phalanges. Digits IV (manus and pes) and V (pes) begin to ossify 
A
Dendropsophus labialis

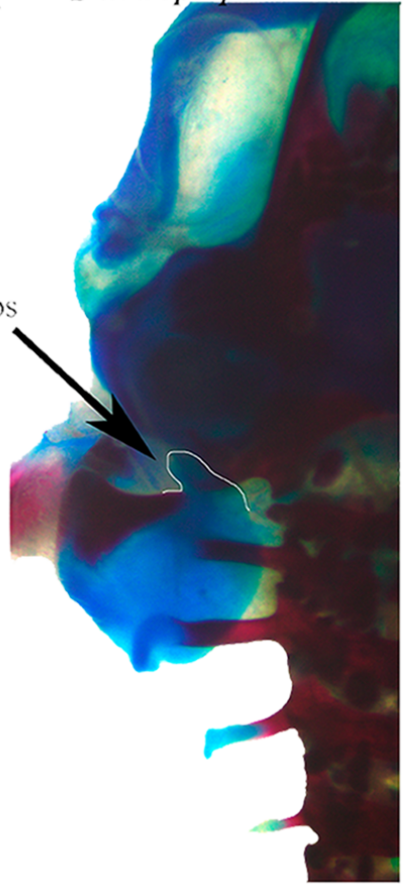

Scinax ruber

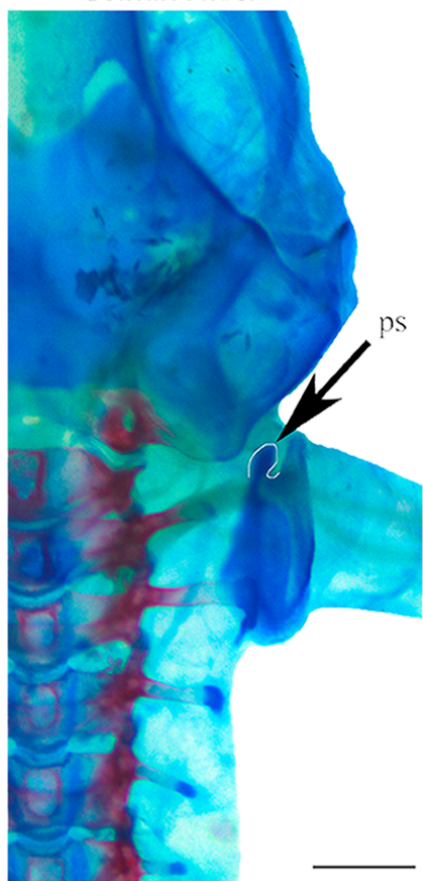

B

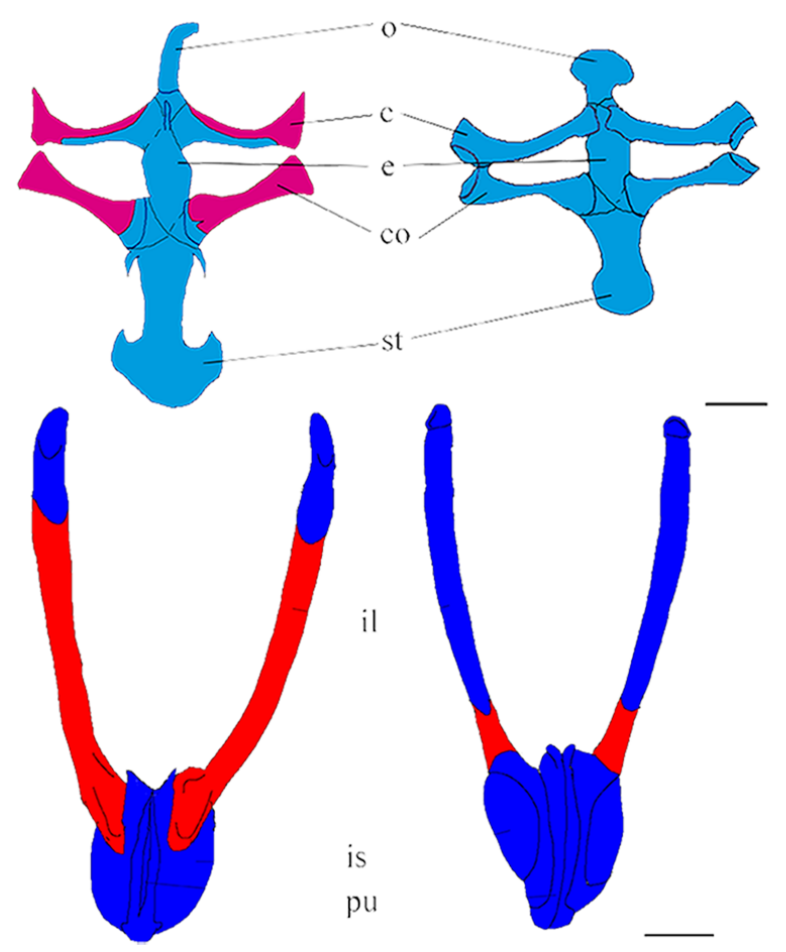

Figure 2 Appendicular skeleton of D. labialis (GS45-MUJ497) and S. ruber (GS45-MUJ6018). (A) Dorsal view of the scapula, (B) Ventral view of the pectoral girdle, (C) Ventral view of the pelvic girdle. Scale $1 \mathrm{~mm}$. c, clavicle; co, coracoid; e, epicoracoid; ps, processus suprascapularis; o, omosternum; st, sternum; il, ilium; is, ischium; pu, pubis Red, ossified; blue, chondrified.

Full-size DOI: 10.7717/peerj.4525/fig-2 


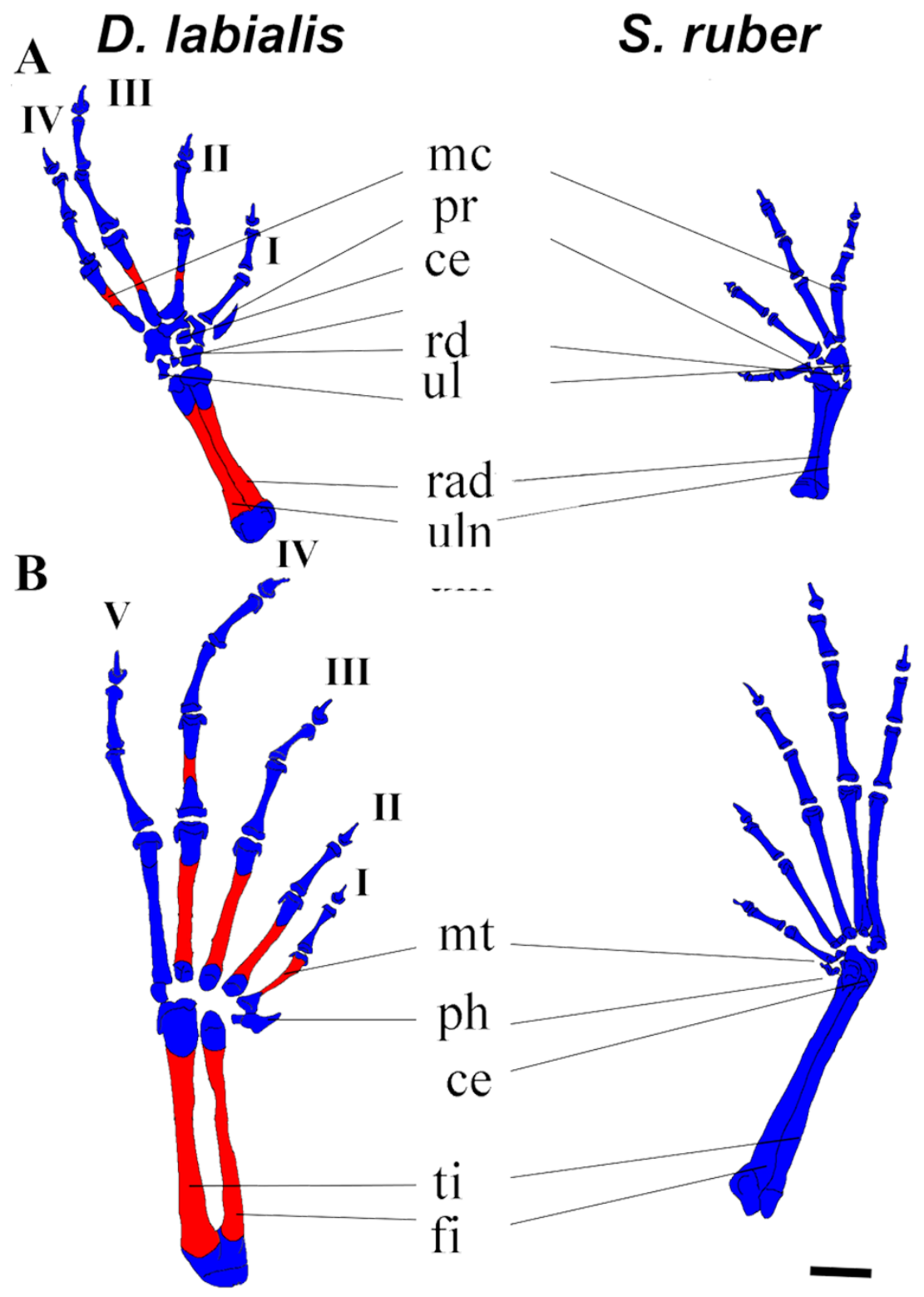

Figure 3 Dorsal view of manus and pes of D. labialis (GS45-MUJ497) and S. ruber (GS45-MUJ6018). (A) Manus, (B) Pes. Scale $1 \mathrm{~mm}$. ce, centrale; fi, fibulare; mc, metacarpal, mt, metatarsus; ph, prehallux; pr, prepollex; rd; radiale; rad, radioulna; ul, ulnare and intermedium; ti, tibiale. I-V, phalanges. Red, ossified; blue, chondrified.

Full-size DOI: 10.7717/peerj.4525/fig-3

by GS42 in D. labialis, although all phalanges are ossified at GS45 in both species (Fig. 3). The carpals were cartilaginous in all specimens and stages examined, and the distal tarsals were cartilaginous in S. ruber. The relative size of carpal elements is $3<4<2<1<$ prehallux and the tarsal elements is $4<5<3<2<1<$ prepollex. Sesamoids are absent from GS25 to GS45. Figure 3A shows the limb elements (central, fibulare, radiale, tibiale, ulnare, and intermedium) at Stage 45. 
A

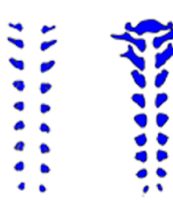

26

29

B

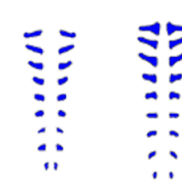

26

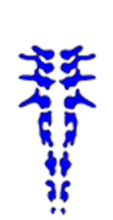

31

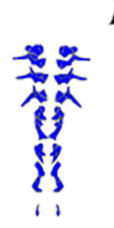

33
Dendropsophus Labialis
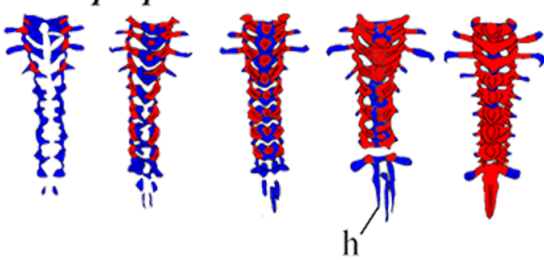

42

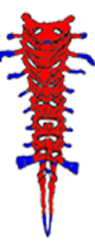

43

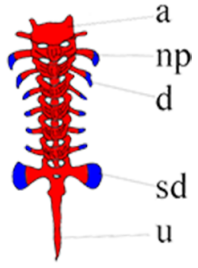

45

Scinax ruber

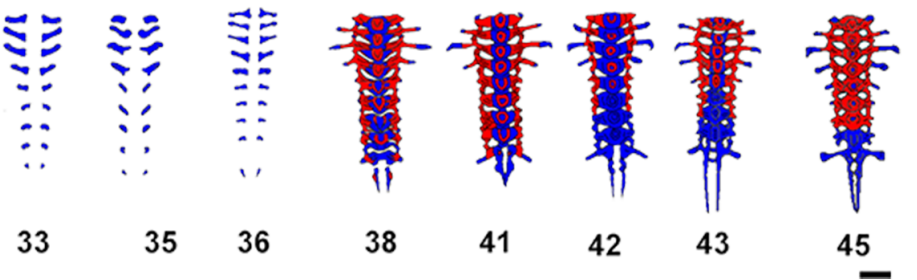

Figure 4 Ventral view of ossification development in vertebral column of $D$. labialis and $S$. ruber at GS 26-45. Scale $1 \mathrm{~mm}$. h, hypochord; a, Atlas; $\mathrm{np}$, neural process; d, diapophysis; sd, sacral diapophysis; $\mathrm{u}$, urostyle Red, ossified; blue, chondrified.

Full-size DOI: 10.7717/peerj.4525/fig-4

\section{Axial skeleton}

The vertebral column is composed of eight procoelous presacral vertebrae, the sacrum, and the urostyle. The notochord diminishes as the tadpoles grow and is completely resorbed by GS44 in both species (Fig. 4). We found that the axial skeleton was more chondrified in D. labialis than in S. ruber. The first postcranial skeletal elements to develop in both species were the nine pairs of semicircular cartilaginous primordia of neural arches, including eight presacral vertebrae, the sacrum, the urostyle and the hypochord. The sacral diapophyseal primordia are cylindrical. The last postsacral vertebra (first coccygeal or Vertebra X sensu Haas, 1999) and the second coccygeal vertebra ossify only in D. labialis by GS45. Simultaneous to the ossification of presacral vertebrae, there is notochord absorption, fusion of the coccygeal elements, and urostyle formation. The urostyle has a bicondylar articulation with the sacral vertebra and the condyles are widely separated in both species (Fig. 4).

The atlas is concave at its point of articulation with the convex occipital condyles at the base of the skull. Semicircular procoelous (sensu Jolie, 1962) vertebral centra begin to develop as early as GS31 in D. labialis and GS32 in S. ruber, increasing the thickness of both the neural arches and the transverse process. The neural arches appear as cartilage at GS33 in both species, completing at GS34 in D. labialis and at GS38 in S. ruber. The arches are fused dorsally at the midline at GS38 in S. ruber and at GS38 in D. labialis. The transverse processes are the first elements to ossify in both species (Tables 1 and 2). Postzygapophyses and prezygapophyses are conspicuous in presacral vertebrae II, III, and IV in both species. Sesamoids are absent from GS25 to GS45. 


\section{Ossification sequence}

The earliest stage examined in both species was GS25. Ossification in D. labialis appears by GS34 and in S. ruber by GS35 (Figs. 1A and 4). Ossification in D. labialis begins with the atlas and the transverse processes, whereas in S. ruber it begins with the parasphenoid, the transverse processes I-VII and neural arches I-III.

The metamorphic climax (MC) begins at GS41 in D. labialis and GS39-40 in S. ruber. We identified seven ranks (I-VII) in D. labialis and five ranks (I-V) in S. ruber (Tables 1 and 2). Ossified elements were perceptible in D. labialis from GS35 to GS45, with 46 ossified elements, and from GS36 to GS43 in S. ruber, with 26 ossified elements. Metamorphic climax in D. labialis was at GS45 with 14 ossified elements and in S. ruber at GS39-40 with seven ossified elements. Of these, the structures in common are the femur, tibia, fibula, humerus, ilium, and radioulna.

\section{DISCUSSION}

Despite Colombia housing the second greatest number of hylid species on the planet, few previous studies have considered developmental ossification of Colombian hylids. The family Hylidae has gone through a number of taxonomic rearrangements, as elucidated by various phylogenetic hypotheses based on molecular, chromosomal, and morphological data from both larvae and adults (Faivovich, 2002; Faivovich et al., 2005; Wiens et al., 2010; Pyron \& Wiens, 2011; Duellman, Marion \& Hedges, 2016). Data from additional morphological studies of Colombia hylids may help to support or refute these hypotheses.

Previous studies of the cranial morphology in hylid tadpoles include Acris crepitans (Maglia, Pugener \& Mueller, 2007), Boana lanciformis (De Sá, 1988; Alcalde \& Rosset, 2003), Boana pulchella (Hoyos et al., 2012), Boana raniceps and Dendropsophus nanus (former Hyla raniceps and Hyla nana Fabrezi \& Lavilla, 1992; Vera Candioti \& Haas, 2004, Dryophytes versicolor (former Hyla versicolor, Sheil et al., 2014), Hyla orientalis (Yildirim \& Kaya, 2014), Julianus acuminatus (former Scinax acuminatus, Fabrezi \& Lavilla, 1992; Faivovich, 2002; Alcalde \& Rosset, 2003; Alcalde et al., 2011), J. uruguayus, J. aff. pinimus (former Scinax uruguayus and Scinax aff. pinima, Alcalde et al., 2011; Rodrigues et al., 2017), Ololygon aromothyella and O. berthae (former Scinax berthae, Rodrigues et al., 2017; Alcalde et al., 2011; Faivovich, 2002), O. skuki (Rodrigues et al., 2017); Scinax granulatus and S. squalirostris (Rodrigues et al., 2017; Alcalde \& Rosset, 2003), S. boulengeri (Rodrigues et al., 2017; Vera Candioti, 2007), S. fuscovariatus (Fabrezi \& Vera, 1997), S. nasicus (Rodrigues et al., 2017; Vera Candioti, 2007; Vera Candioti, Lavilla \& Echeverría, 2004; Fabrezi \& Vera, 1997), S. ruber (Haas, 1996). For a complete overview of the findings of these studies see Appendix 1.

Several of the differences between the two species examined here present interesting avenues for future examination. For example, the processus ethmoidalis of the quadrate in S. ruber is wide, and it is not clearly distinct from the processus articularis. In contrast, the processes of D. labialis are easily distinguishable and similar to that described by Alcalde $\&$ Rosset (2003), who found similar features in Boana raniceps compared with the Scinax group (S. squalirostris and S. granulatus, Scinax ruber group). The palatoquadrate is similar 
but the processus ascendens of the palatoquadrate in D. labialis is wider than in S. ruber, and the distal side of the cornu trabeculae extend posteriorly toward the otic capsule. The anterior region of the palatoquadrate is distinctively broader in S. ruber than in D. labialis, and in S. ruber the dorsomedial process is wider than the ventromedial process in D. labialis.

When comparing the development of D. labilis with D. nanus (Vera Candioti, Lavilla \& Echeverría, 2004 and Alcalde \& Rosset, 2003), we found that D. labialis can be differentiated by the reduction of the buccopharyngeal and branchial basket structures and presence of processus quadrato etmoidale in ventral view. On the other hand, the information that is available for Scinax species (Fabrezi \& Lavilla, 1992; Haas, 1996; Fabrezi \& Vera, 1997; Faivovich, 2002; Alcalde \& Rosset, 2003; Vera Candioti, Lavilla \& Echeverría, 2004; Vera Candioti, 2007; Alcalde et al., 2011; Rodrigues et al., 2017) reveal that there are a numerous variations that requires extending the morphological studies in tadpoles.

Scinax ruber presents alae and corpus of suprarostral cartilage with deeper notches. The chondrocranium, hyobranchial apparatus, and the suprarostral body are joined syndesmotically as found by Vera Candioti (2007) in microphagous tadpoles of S. nasicus and S. boulengeri. Dendropsophus labialis, as Dendropsophus nanus, shows a suprarostral cartilage with corpus and alae forming a continuous structure, which is evidently associated with a deviation of the macrophogous mechanisms described by Alcalde \& Rosset (2003).

The lateral development of the crista parotica is more prominent in S. ruber than in D. labialis. It is possible that some of the variations in the anatomical structures of the otic capsule are functionally related to perception of vocalizations (i.e., same species recognition) in adult stages, but experiments must be conducted to confirm the relationship of these anatomical structures with hearing physiological functions (Ruggero \& Temchin, 2002; Boistel et al., 2013).

The chondrification of skull in S. ruber is faint when viewed laterally, and foramina are not clearly visualized. By contrast, in D. labialis much more blue coloration was observed. This could be due to abundant chondrification of these parts or the early developmental stages of this anatomical area, in which allowed differentiation of craniopalatine carotid foramina.

Although the sample size for the D. labialis is very small in comparison with S. ruber, D. labialis exhibited more ossified elements with stronger chondrification and less intraspecific variation, while $S$. ruber showed more intraspecific variation and less overall chondrification in the samples (Fig. 1). D. labialis presented uniformly stained (ossified) elements in all individuals (Table 3 ).

This variation between $S$. ruber and D. labialis could be caused by intrinsic factors that determine the timing of development or by extrinsic factors affecting osteogenesis (Vera \& Ponssa, 2014). It may not be a coincidence that $S$. ruber is a generalist species and D. labialis is an endemic one (Frost, 2018).

Haas (1996) reported that the ceratohyalia II-IV are fused in Scinax ruber and Megophrys montana nasuta, characteristics that separate them from other species. We confirmed this observation in S. ruber but not in D. labialis. The ceratohyal in D. labialis has a process on the articular condyle that is not present in S. ruber. Alcalde \& Rosset (2003) found this 
process in both S. granulatus and S. squalirostris. Spicules I-III on the posterior margin of the hypobranchial plate are present in D. labialis and S. ruber, but spicule IV is not.

Copula II is present in both species. Copula I is present in D. labialis as in S. squalirostris, but absent in S. ruber as in S. granulatus, Boana raniceps (Alcalde \& Rosset, 2003), and Tlalocohyla smithii (Vera Candioti \& Haas, 2004). Although the presence of copula I is extremely variable in hylids and is shared by all non-hylids (Vera Candioti \& Haas, 2004), a relationship between this structure and the ecological function that it performs (e.g., prey utilization) has not been identified.

Additional characteristics of the developmental morphology of these species could place them with other hylids that have been studied previously. For example, the urostyle of D. labialis and S. ruber forms a bicondylar articulation with the sacral vertebra, and the condyles are widely separated. The shoulder girdle of both species present differences in the shape of the omosternum and sternum at GS 45. D. labialis and S. ruber present suprascapular processes in tadpoles and adults similar to those in other hylids (Hypsiboas lanciformis, De Sá, 1988; Boana pulchella, Hoyos et al., 2012; Pseudacris crucifer and Acris blanchardi, Havens, 2010 and A. crepitans, Maglia, Pugener \& Mueller, 2007) but is absent in Scinax catharinae clade (Faivovich et al., 2005).

Variations of larval characters between Scinax and Dendropsophus have been included in several phylogenetic studies (Fabrezi \& Vera, 1997; Haas, 1996; Haas, 1999; Haas, 2003; Alcalde \& Rosset, 2003; Vera Candioti, 2007). In our study, the skeleton shows significant differences between the species S. ruber and D. labialis, the elements ossified in S. ruber exhibit more intraspecific variability than in D. labialis (see Table 3).

Regarding ossification sequence, the first bones ossified in the cranium were the exoccipital, the frontoparietal, and the parasphenoid by GS 36. Haas (1999) found that in S. ruber this occurred one stage later by GS37. Similar to those that Haas (1999) described for other hylids, the ossification of the vertebrae begins from the centra of the presacral vertebrae and continues ventrally along the notochord, forming osseous rings around the notochord in both species. We found that the ossification of the centra in both species we studied begins ventrally and proceeds dorsally. Haas (1999) recorded the transverse processes of presacral vertebrae II-III as the first to ossify, while we found that it was the ossification of neural arches proceeds from I to IX in D. labialis (GS37) and from I to III in S. ruber (GS36) (Fig. 4).

The detection of more intraspecific variability in S. ruber than in D. labialis could also be due to the presence of more intra-generic diversity in the S. ruber clade. Alcalde \& Rosset (2003) associated the type of feeding with the development of the lateral anterohyal process of the ceratohyal, between species with macrophage larvae (Dendropsophus nanus), and scraping microphages (Boana pulchellus, Julianus acuminatus and S. nasicus). This may indicate that morphological characteristics of the jaw may be involved in the particular feeding behaviors of these tadpoles, and therefore these traits would help to distinguish the species (Appendix 1).

Differences between the ossification sequences of these two species are also evident when examining the ossification ranks and number of ossified bones. In particular, D. labialis has more ranks in the sequence and more elements that begin ossification prior 
to metamorphosis. With respect to the postcranium, the number of elements ossified appears earlier in D. labialis than in S. ruber. Because Gosner stages are based on external characteristics that rely on underlying skeletal change, it is only a relative measure of timing and should not be used as a way to compare species. Instead, we compared the relative timing of events in the ossification sequence by examining the order of onset of ossification of each element. Nunn \& Smith (1998), on page 86, considered “ontogeny may be ordered by age, size, or stage; none of these measures are useful for comparing ontogeny across significantly divergent taxa".

Table 4 outlines the ossification sequences of different species of the family Hylidae. The number of ranks that include elements of the skull and postcranium vary from one to five. The number of ranks increases when postcranial elements are included. Weisbecker \& Mitgutsch (2010), Harrington, Harrison \& Sheil (2013), and Sheil et al. (2014) used similar ranked ossification sequence data to reconstruct phylogenetic trees of amphibians in the families of Leptodactylidae, Ranidae, and Bufonidae. These researchers suggested using cranium and postcranium data, relating them to the type of development, and to include sequences of fossils, as far as possible.

Although the morphology and systematics of amphibians have been extensively studied (Cannatella \& Trueb, 1988; De Sá \& Hillis, 1990; Báez \& Pugener, 2003; Roelants \& Bossuyt, 2005; Faivovich et al., 2005; Frost et al., 2006; Pyron \& Wiens, 2011; Duellman, Marion $\&$ Hedges, 2016), additional comprehensive descriptions of skeletal development and ossification sequences are needed to truly understand patterns of heterochrony in the group. Some of the biological implications of heterochrony, which are well known in amphibians (Alberch, 1985; Reilly, Wiley \& Meinhardt, 1991), include changes in structure, and changes in the rate of growth of entire organisms (Raff, 1996; Smith, 2001; Smith, 2002; Smith, 2003). Some scholars have recognized that heterochrony may work as modules of developmental events with evolutionary implications that can promote or restrict the development of individual morphologies (Wagner, 1996).

Studies that have used statistical methods (e.g., Parsimov) to analyze ossification sequences have revealed heterochrony in the timing of onset of ossification in some cranial elements such as parasphenoid and prootic in S. ruber vs. H. pulchellus (Hoyos et al., 2012), or the frontoparietal, dentary, and maxilla in D. labialis vs. Pseudis platensis (Fabrezi \& Goldberg, 2009). In our study, we found that the parasphenoid was the first element to ossify in both D. labialis and S. ruber, and the exoccipital, frontoparietal, and prootic were the second elements to ossify in both species.

It is possible that the difference in cartilage formation between the two species examined herein is due to paracrine factors induced in cells that express the mesodermal transcription factors involved in the activation of genes specific to cartilage (Gilbert, 2000; Kozhemyakina, Lassar \& Zelzer, 2015); however, we did not account for these factors. Additionally, the intraspecific variation in the ossified elements between these species could be linked to specific genes (Raff, 1996). 


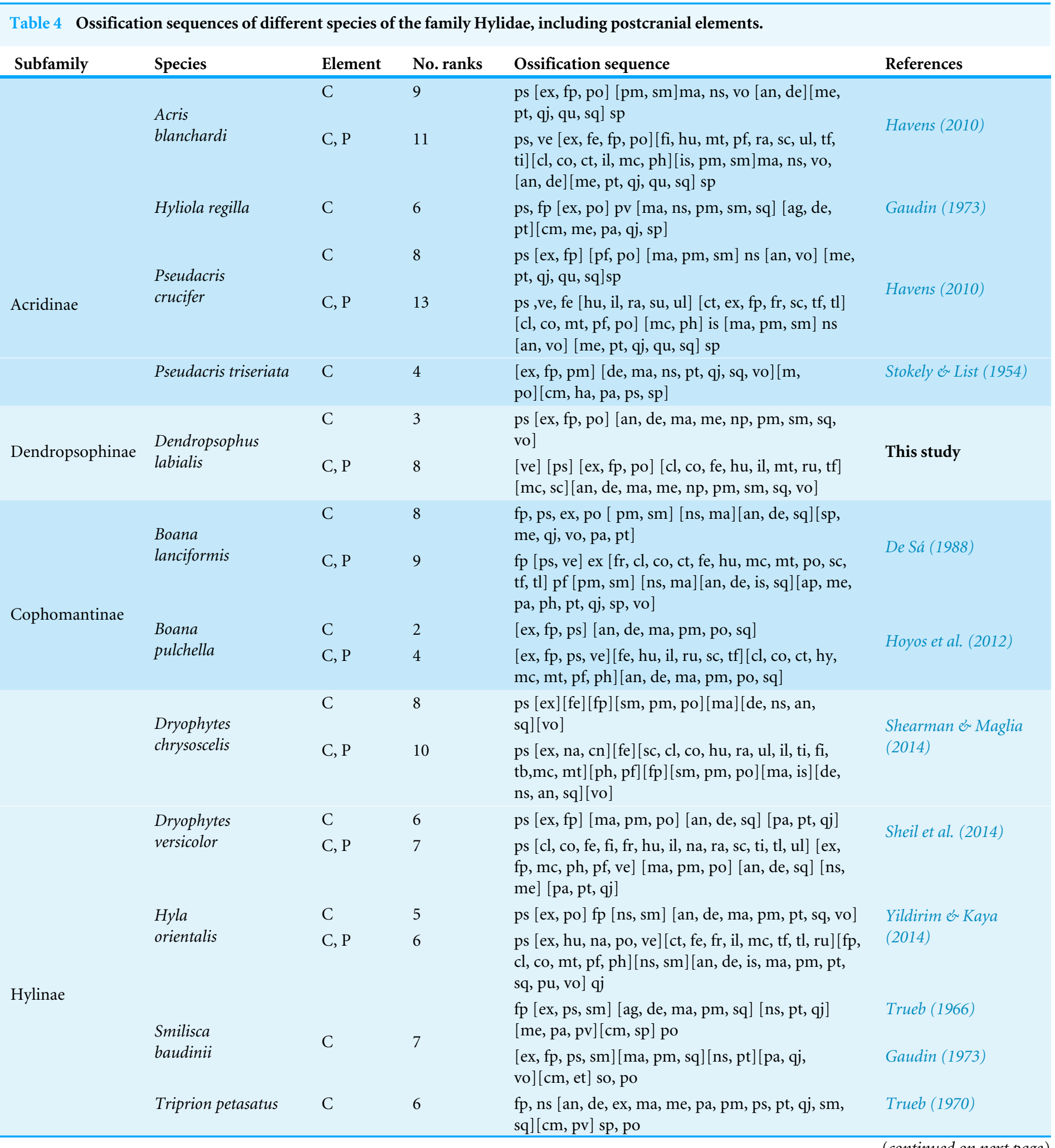


Table 4 (continued)

\begin{tabular}{|c|c|c|c|c|c|}
\hline Subfamily & Species & Element & No. ranks & Ossification sequence & References \\
\hline \multirow{4}{*}{ Lophyohylinae } & \multirow{4}{*}{$\begin{array}{l}\text { Osteopilus } \\
\text { septentrionalis }\end{array}$} & & 3 & $\begin{array}{l}\text { fp, sm [ag, cm, de, et, ex, ma, me, ns, pa, pm, po, } \\
\text { ps, pt, qj, sq, vo] }\end{array}$ & Trueb (1966) \\
\hline & & $\mathrm{C}$ & 7 & $\begin{array}{l}\mathrm{fp}, \mathrm{sm}[\mathrm{an}, \mathrm{de}, \mathrm{ex}, \mathrm{ma}, \mathrm{ns}, \mathrm{pm}, \mathrm{ps}, \mathrm{pt}, \mathrm{pv}, \mathrm{sq}] \mathrm{pa} \\
\text { qj }[\mathrm{me}, \mathrm{po}, \mathrm{sp}] \mathrm{cm}\end{array}$ & Trueb (1970) \\
\hline & & & 5 & $\begin{array}{l}{[\mathrm{fp}, \mathrm{sm}][\mathrm{ag}, \mathrm{de}, \mathrm{ex}, \mathrm{ns}, \mathrm{ma}, \mathrm{pm}, \mathrm{ps}, \mathrm{pt}, \mathrm{pv}, \mathrm{sq}] \mathrm{pa}} \\
\text { qj }[\mathrm{po}, \mathrm{sp}]\end{array}$ & Gaudin (1973) \\
\hline & & $\mathrm{C}, \mathrm{P}$ & 13 & $\begin{array}{l}\mathrm{ps}, \mathrm{ve}, \mathrm{fe}[\mathrm{hu}, \mathrm{il}, \mathrm{ra}, \mathrm{su}, \mathrm{ul}][\mathrm{ct}, \mathrm{ex}, \mathrm{fp}, \mathrm{fr}, \mathrm{sc}, \mathrm{tf}, \mathrm{tl}] \\
{[\mathrm{cl}, \mathrm{co}, \mathrm{mt}, \mathrm{pf}, \mathrm{po}][\mathrm{mc}, \mathrm{ph}] \text { is }[\mathrm{ma}, \mathrm{pm}, \mathrm{sm}] \mathrm{ns}} \\
{[\mathrm{an}, \mathrm{vo}][\mathrm{me}, \mathrm{pt}, \mathrm{qj}, \mathrm{qu}, \mathrm{sq}] \mathrm{sp}}\end{array}$ & Sheil et al. (2014) \\
\hline Pseudinae & Pseudis platensis & $\mathrm{C}$ & 5 & {$[\mathrm{fp}, \mathrm{ps}][\mathrm{ex}, \mathrm{po}][\mathrm{ns}, \mathrm{pm}, \mathrm{sq}] \mathrm{ma}[\mathrm{de}, \mathrm{pt}, \mathrm{vo}]$} & $\begin{array}{l}\text { Fabrezi \& Goldberg } \\
\text { (2009) }\end{array}$ \\
\hline \multirow{2}{*}{ Scinaxinae } & \multirow{2}{*}{$\begin{array}{l}\text { Scinax } \\
\text { ruber }\end{array}$} & $\mathrm{C}$ & 3 & $\begin{array}{l}\mathrm{ps},[\mathrm{fp}, \mathrm{po}][\mathrm{an}, \mathrm{de}, \mathrm{ma}, \mathrm{me}, \mathrm{np}, \mathrm{pc}, \mathrm{pm}, \mathrm{sm}, \mathrm{sq} \\
\text { vo] }\end{array}$ & \multirow{2}{*}{ This study } \\
\hline & & $\mathrm{C}, \mathrm{P}$ & 7 & $\begin{array}{l}\text { ps, ve }[e x, f p, p o][f e, h u, i l, r u, s c, t f, t l] \text { is }[a n, d e, \\
\text { ma, me, pm, pc] [np, sm, sq, vo] }\end{array}$ & \\
\hline
\end{tabular}

Notes.

C, cranium; P, poscranium; ag, angular; an, angulosplenial; ap, plectral apparatus; cl, clavicle; cu, columella; co, coracoid; ct, cleithrum; de, dentary; et, ethmoid; ex, exoccipital; fe, femur; fi, fibula; fp, frontoparietalis; fr, fibulare; ha, hyoid apparatus; hu, humerus; hy, hypochord; il, ilium; is, ischium; ma, maxilla; mc, metacarpals; me, mentomeckelian; mt, metatarsals; na, neural arches; nc, neural center; np, neopalatine; ns, nasal; pa, palatine; pc, coronoid process; pr, presacral vertebrae; pf, phalanges of feet; ph, phalanges of manus; pm, premaxilla; po, prootic; ps, parasphenoid; pt, pterygoid; pv, pre vomer; qi, quadratojugal; qu, quadrate; ra, radius; ru, radioulna; sc, scapula; sm, septomaxilla; sp, sphenethmoid; sq, squamosal; su, suprascapula; ti, tibia; tf, tibiofibula; tl, tibiale; tp, transverse process; ul, ulna; ve, vertebra (including na, nc, pr, tp); vo, vomer; C, cranial elements; P, postcranial elements.

(Rank $=$ absolute time of ossification of various structures simultaneously).

\section{CONCLUSIONS}

The contribution of ontogenetic data (development and ossification sequences of skeletal structures) provides further information to help understand the interactions between ontogeny and phylogeny in morphological and ecological diversity of frogs. Ossification sequence data combined with evolutionary hypotheses may shed light on patterns of development to be used in future phylogenetic hypotheses. As Larson, De Sá \& Arrieta (2003) suggested, "variation in chondrocranial morphology in larval anurans can be phylogenetically informative, even among closely related taxa".

\section{ACKNOWLEDGMENTS}

We want to thank Timothy Sosa for help with the English translation. We appreciate the contributions of the reviewers.

\section{ADDITIONAL INFORMATION AND DECLARATIONS}

\section{Funding}

This work was supported by Pontificia Universidad Javeriana, Paläontologisches Institut und Museum, Universität Zürich (Phenotypic and developmental plasticity and sequence heterochrony in anurans ID: 00003918), and by the Departamento Administrativo de Ciencias, Tecnología e Innovación-COLCIENCIAS (Colombian government Institution-Convocatoria 511/2010). The funders had no role in study design, data collection and analysis, decision to publish, or preparation of the manuscript. 


\section{Grant Disclosures}

The following grant information was disclosed by the authors:

Pontificia Universidad Javeriana.

Paläontologisches Institut und Museum.

Universität Zürich: 00003918.

Departamento Administrativo de Ciencias, Tecnología e Innovación-COLCIENCIAS

(Colombian government Institution-Convocatoria 511/2010).

\section{Competing Interests}

The authors declare there are no competing interests.

\section{Author Contributions}

- Angélica Arenas-Rodríguez conceived and designed the experiments, performed the experiments, analyzed the data, contributed reagents/materials/analysis tools, prepared figures and/or tables, authored or reviewed drafts of the paper, approved the final draft.

- Juan Francisco Rubiano Vargas conceived and designed the experiments, performed the experiments, approved the final draft.

- Julio Mario Hoyos conceived and designed the experiments, analyzed the data, contributed reagents/materials/analysis tools, authored or reviewed drafts of the paper, approved the final draft.

\section{Animal Ethics}

The following information was supplied relating to ethical approvals (i.e., approving body and any reference numbers):

The samples are from the museum of Javeriana University, Bogotá Colombia.

\section{Data Availability}

The following information was supplied regarding data availability:

Specimens belong to the Museo de Historia Natural "Lorenzo Uribe" at the Universidad Javeriana (MUJ) and the Instituto de Ciencias Naturales at the Universidad Nacional in Bogotá-Colombia (ICN). Dendropsophus labialis (MUJ 9250) and Scinax ruber (MUJ 3727, MUJ 6178, ICN 46015-46017).

\section{Supplemental Information}

Supplemental information for this article can be found online at http://dx.doi.org/10.7717/ peerj.4525\#supplemental-information.

\section{REFERENCES}

Alberch P. 1985. Problems with the interpretation of developmental sequences. Systematic Zoology 34:46-58 DOI 10.2307/2413344.

Alcalde L, Rosset SD. 2003. Descripción y comparación del condrocráneo en larvas de Hyla raniceps (Cope, 1862) Scinax granulatus (Peters, 1863) y Scinax squalirostris (Lutz, 1925) (Anura: Hylidae). Cuadernos de Herpetología 17:33-49. 
Alcalde L, Vera Candioti MF, Kolenc F, Borteiro C, Baldo D. 2011. Cranial anatomy of tadpoles of five species of Scinax, Hylidae, Hylinae. Zootaxa 2787:19-36.

Avilán P, Hoyos JM. 2006. Osteology of Eleutherodactylus bogotensis (Amphibia, Anura, Leptodactylidae) from the Parque Nacional Natural Chingaza, Cundinamarca (Colombia). Caldasia 28:89-109.

Báez AM, Pugener LA. 2003. Ontogeny of a new Palaeogene pipid frog from southern South American and xenopodinomorph evolution. Zoological Journal of the Linnean Society 139:439-476 DOI 10.1046/j.1096-3642.2003.00085.x.

Banbury B, Maglia AM. 2006. Skeletal development of the Mexican spade foot, Spea multiplicata (Anura: Pelobatidae). Journal of Morpology 267:803-821 DOI 10.1002/jmor.10441.

Boistel R, Aubin T, Cloetens P, Peyrin F, Scotti T, Herzog P, Gerlach J, Pollet N, Aubry JF. 2013. How minute sooglossid frogs hear without a middle ear. Proceedings of the National Academy of Sciences of the United States of America 2:15360-15364 DOI 10.1073/pnas.1302218110.

Bowatte G, Meegaskumbura M. 2011. Morphology and ecology of tadpoles of $R a$ manella obscura (Anura: Microhylidae). Ceylon Journal of Science 40:109-120 DOI 10.4038/cjsbs.v40i2.3927.

Cannatella DC. 1999. Architecture: cranial and axial musculoskeleton. In: McDiarmid RW, Altig R, eds. Tadpoles: the biology of anuran larvae. Chicago: University of Chicago Press, 52-91.

Cannatella DC, Trueb L. 1988. Evolution of pipoid frogs: intergeneric relationships of the aquatic frog family Pipidae (Anura). Zoological Journal of the Linnean Society 94:1-38 DOI 10.1111/j.1096-3642.1988.tb00880.x.

De Sá RO. 1988. Chondrocranium and ossification sequence of Hyla lanciformis. Journal of Morphology 195:345-355 DOI 10.1002/jmor.1051950308.

De Sá RO, Hillis DM. 1990. Phylogenetic relationships of the pipid frogs Xenopus and Silurana: an integration of ribosomal DNA and morphology. Molecular Biology and Evolution 7:365-376 DOI 10.1093/oxfordjournals.molbev.a040612.

Dingerkus G, Uhler LD. 1977. Enzyme clearing of Alcian blue stained whole small vertebrates for demonstration of cartilage. Stain Technology 52:229-232 DOI 10.3109/10520297709116780.

Duellman WE, Marion AB, Hedges SB. 2016. Phylogenetics, classification, and biogeography of the tree frogs (Amphibia: Anura: Arboranae). Zootaxa 4104:1-109 DOI 10.11646/zootaxa.4104.1.1.

Duellman WE, Trueb L. 1986. Biology of amphibians. New York: McGraw-Hill Inc. Fabrezi M, Goldberg J. 2009. Heterochrony during skeletal development of Pseudis platensis (Anura, Hylidae) and the early offset of skeleton development and growth. Journal of Morphology 270:205-220 DOI 10.1002/jmor.10680.

Fabrezi M, Lavilla EO. 1992. Estructura del condrocráneo y esqueleto hiobranquial en larvas de algunos hílidos neotropicales (Anura: Hylidae). Acta Zoologica Lilloana 41:155-164. 
Fabrezi M, Vera R. 1997. Caracterización morfológica de larvas de anuros del Noroeste argentino. Cuadernos de Herpetología 11:37-49.

Faivovich JC. 2002. A cladistics analysis of Scinax (Anura: Hylidae). Cladistics 18:367-393 DOI 10.1111/j.1096-0031.2002.tb00157.x.

Faivovich JC, Haddad CFB, García P, Frost DR, Campbell JA, Wheeler WC. 2005. Systematic review of the frog family Hylidae, with special reference to Hylinae: phylogenetic analysis and taxonomic revision. Bulletin of the American Museum of Natural History 294:1-240 DOI 10.5531/sd.sp.12.

Frost DR. 2018. Amphibian species of the world: an online reference. New York: American Museum of Natural History New York.

Frost DR, Grant T, Faivovich JC, Bain RH, Haas A, Haddad CFB, De Sa RO, Channing A, Wilkinson M, Donnellan SC, Raxworthy CJ, Campbell JA, Blotto BL, Moler P, Drewes RC, Nussbaum RA, Lynch JD, Green DM, Wheeler WC. 2006. The amphibian tree of life. Bulletin of the American Museum of Natural History 297:1-370 DOI 10.5531/sd.sp.13.

Gaudin AJ. 1973. The development of the skull in the Pacific tree frog, Hyla regilla. Herpetologica 29:205-218.

Gilbert SF. 2000. Chapter 1: the anatomical tradition: evolutionary embryology: embryonic homologies. In: Developmental biology. Sunderland: Sinauer Associates, Inc.

Gosner KL. 1960. A simplified table for staging anuran embryos and larvae with notes on identification. Herpetologica 16:183-190.

Haas A. 1995. Cranial features of dendrobatid larvae (amphibia: Anura: Dendrobatidae). Journal of Morphology 224:241-264 DOI 10.1002/jmor.1052240302.

Haas A. 1996. Das larvale cranium von Gastrotheca riobambae und seine metamorphose (Amphibia, Anura, Hylidae). Verhandlungen des Naturwissenschaftlichen Vereins in Hamburg 36:33-162.

Haas A. 1997. The larval hyobranchial apparatus of discoglossoid frogs: its structure and bearing on the systematics of the Anura (Amphibia: Anura). Journal of Zoological Systematics and Evolutionary Research 35:179-197

DOI 10.1111/j.1439-0469.1997.tb00422.x.

Haas A. 1999. Larval and metamorphic skeletal development in the fast-developing frog Pyxicephalus adspersus (Anura, Ranidae). Zoomorphology 119:23-35 DOI 10.1007/s004350050078.

Haas A. 2003. Phylogeny of frogs as inferred from primarily larval characters (Amphibia: Anura). Cladistics 19:23-89 DOI 10.1111/j.1096-0031.2003.tb00405.x.

Hall JA, Larsen JH. 1998. Postembryonic ontogeny of the spadefoot toad, Scaphiopus intermontanus (Anura: Pelobatidae): Skeletal morphology. Journal of Morphology 238:179-244 DOI 10.1002/(SICI)1097-4687(199811)238:2<179::AID-JMOR4>3.0.CO;2-6.

Harrington SM, Harrison LB, Sheil CA. 2013. Ossification sequence heterochrony among amphibians. Evolution and Development 15:344-364 DOI 10.1111/ede.12043. 
Havens SB. 2010. The role of skeletal development in body size evolution of two North American frogs. Master thesis, Missouri University of Science and Technology.

Higgins GM. 1921. The nasal organ in amphibia. Illinois Biological Monographs 6:3-90.

Hoyos JM, Sánchez-Villagra MR, Carlini AA, Mitgutsch C. 2012. Skeletal development and adult osteology of Hypsiboas pulchellus (Anura: Hylidae). Acta Herpetologica 7:119-138 DOI 10.13128/Acta_Herpetol-9600.

International Committee on Veterinary Anatomical Nomenclature (ICVAN). 1973. Nomina anatomica veterinaria. Second edition. Vienna: International Committee on Veterinary Anatomical Nomenclature under the financial responsibility of the World Association of Veterinary Anatomists.

Jolie M. 1962. Chordata Morphology. New York: Reinhold Publ. Co.

Jungfer KH. 2017. On Warszewicz's trail: the identity of Hyla molitor O. Schmidt, 1857. Salamandra 53:18-24.

Kozhemyakina E, Lassar AB, Zelzer E. 2015. A pathway to bone: signaling molecules and transcription factors involved in chondrocyte development and maturation. Development 142:817-831 DOI 10.1242/dev.105536.

Larson PM, De Sá RO, Arrieta D. 2003. Chondrocranial, hyobranchial and internal oral morphology in larvae of the basal bufonid genus Melanophryniscus (Amphibia: Anura). Acta Zoologica Stockholm 84(2):145-154 DOI 10.1046/j.1463-6395.2003.00140.x.

Maglia AM, Pugener LA. 1998. Skeletal development and adult osteology of Bombina orientalis (Anura: Bombinatoridae). Herpetology 54:344-363.

Maglia AM, Pugener LA, Mueller JM. 2007. Skeletal morphology and postmetamorphic ontogeny of Acris crepitans (Anura: Hylidae): a case of miniaturization in frogs. Journal of Morphology 268:194-223 DOI 10.1002/jmor.10508.

Nunn CL, Smith KK. 1998. Statistical analyses of developmental sequences: the craniofacial region in marsupial and placental mammals. American Naturalist 152:82-101 DOI 10.1086/286151.

Orton GL. 1953. The systematics of vertebrate larvae. Systematic Zoology 2:63-75 DOI $10.2307 / 2411661$.

Parker WK. 1876. On the structure and development of the skull in the Batrachia. Part II. Philosophical Transactions of the Royal Society 166:648-699.

Pugener LA, Maglia AM. 2007. Skeletal morphology and development of the olfactory region of Spea (Anura: Scaphiopodidae). Journal of Anatomy 211:754-768 DOI 10.1111/j.1469-7580.2007.00826.x.

Pyron A, Wiens JJ. 2011. A large-scale phylogeny of Amphibia including over 2800 species, and a revised classification of extant frogs, salamanders, and caecilians. Molecular Phylogenetic Evoltion 61:543-583 DOI 10.1016/j.ympev.2011.06.012.

Raff RA. 1996. The shape of life: genes, development and the evolution of animal form. Chicago: University of Chicago Press.

Reilly SM, Wiley EO, Meinhardt DJ. 1991. An integrative approach to heterochrony: the distinction between interspecific and intraspecific phenomena. Biological Journal of the Linnean Society 60:119-143 DOI 10.1111/j.1095-8312.1997.tb01487.x. 
Rodrigues GDV, Do Nascimento FAC, De Almeida JPFA, Mott T. 2017. The tadpole of Scinax skuki, Anura: Hylidae from the type locality, with a description of its larval skeleton. Studies on Neotropical Fauna and Environment 52:204-215 DOI 10.1080/01650521.2017.1342485.

Roelants K, Bossuyt F. 2005. Archaeobatrachian paraphyly and pangaean diversification of crown-group frogs. Systematc Bology 54:111-126 DOI 10.1080/10635150590905894.

Roček Z. 1981. Cranial anatomy of frogs of the family Pelobatidae Stannius, 1856, with outlines of their phylogeny and systematics. Acta Universitatis Carolinae Biologica 1980:1-164.

Ruggero MA, Temchin AN. 2002. The roles of the external, middle, and inner ears in determining the bandwidth of hearing. Proceedings of the National Academy of Sciences of the United States of America 99:13206-13210 DOI 10.1073/pnas.202492699.

Shearman RM, Maglia AM. 2014. Osteological development of Cope's gray treefrog, Hyla chrysoscelis. Acta Zoologica Stockholm 96:181-198 DOI 10.1111/azo.120662.

Sheil CA, Alamillo H. 2005. Osteology and skeletal development of Phyllomedusa vaillantii (Anura: Hylidae: Phyllomedusinae) and a comparison of this arboreal species with a terrestrial member of the genus. Journal of Morphology 265:343-368 DOI 10.1002/jmor.10362.

Sheil CA, Jorgensen M, Tulenko F, Harrington S. 2014. Variation in timing of ossification affects inferred heterochrony of cranial bones in Lissamphibia. Evolution and Development 16:292-305 DOI 10.1111/ede.1209.

Smith KK. 2001. Heterochrony revisited: the evolution of developmental sequences. Biological Journal of the Linnean Society 73:169-186 DOI 10.1006/bijl.2001.0535.

Smith KK. 2002. Sequence heterochrony and the evolution of development. Journal of Morphology 252:82-97 DOI 10.1002/jmor.10014.

Smith KK. 2003. Time's arrow: heterochrony and the evolution of development. International Journal of Biomedical Research 47:613-621.

Starrett PH. 1973. Evolutionary patterns in larval morphology. In: Vial JL, ed. Evolutionary biology of the anurans: contemporary research on major problems. Columbia: University of Missouri Press, 251-271.

Stokely PS, List JC. 1954. The progress of ossification in the skull of the cricketfrog Pseudacris nigrita triseriata. Copeia 3:211-217 DOI 10.2307/1439196.

Trueb L. 1966. Morphology and development of the skull in the frog Hyla septentrionalis. Copeia 1966:562-573 DOI 10.2307/1441083.

Trueb L. 1970. Evolutionary relationships of casque-headed tree frogs with co-ossified skulls (family Hylidae). University of Kansas. Museum of Natural History 18:547-716.

Vera MC, Ponssa ML. 2014. Skeletogenesis in anurans: cranial and postcranial development in metamorphic and postmetamorphic stages of Leptodactylus bufonius (Anura: Leptodactylidae). Acta Zoologica 95:44-62 DOI 10.1111/azo.12007.

Vera Candioti MF. 2007. Anatomy of anuran tadpoles from lentic water bodies: systematic relevance and correlation with feeding habits. Zootaxa 1600:1175-5326 DOI 10.11646/zootaxa.1600.1.1. 
Vera Candioti MF, Haas A. 2004. Three-dimensional reconstruction of the hyobranchial apparatus of Hyla nana tadpoles (Anura: Hylidae). Cuadernos de Herpetologa 18:3-15.

Vera Candioti MF, Lavilla EO, Echeverría DD. 2004. Feeding mechanisms in two treefrogs, Hyla nana and Scinax nasicus (Anura: Hylidae). Journal of Morphology 261:206-224 DOI 10.1002/jmor.10239.

Wagner GP. 1996. Homologues, natural kinds and the evolution of modularity. American Zoology 36:36-43 DOI 10.1093/icb/36.1.36.

Wassersug RJ. 1980. Internal oral features of larvae from eight families: functional, systematic, evolutionary and ecological considerations. Miscellaneous publication-University of Kansas, Museum of Natural History 68:1-146 DOI 10.5962/bhl.title.16230.

Wassersug RJ, Heyer WR. 1988. A survey of internal oral features of leptodactyloid larvae (Amphibia: Anura). Smithsonian Contributions to Zoology 457:1-99.

Weisbecker V, Mitgutsch C. 2010. A large-scale survey of heterochrony in anuran cranial ossification patterns. Journal of Zoological Systematics and Evolutionary Research 48:332-347 DOI 10.1111/j.1439-0469.2010.00570.x.

Wiens JJ, Kuczynski CA, Hua X, Moen DS. 2010. An expanded phylogeny of tree frogs, Hylidae based on nuclear and mitochondrial sequence data. Molecular Phylogenetic Evolution 55:871-882 DOI 10.1016/j.ympev.2010.03.013.

Yildirim E, Kaya U. 2014. Comparative skeletogenesis of the oriental tree frog Hyla orientalis (Anura: Hylidae). Zoologischer Anzeiger 253:361-371

DOI 10.1016/j.jcz.2014.04.002. 